$y^{9.1}$

RFP-1391

November 24, 1969
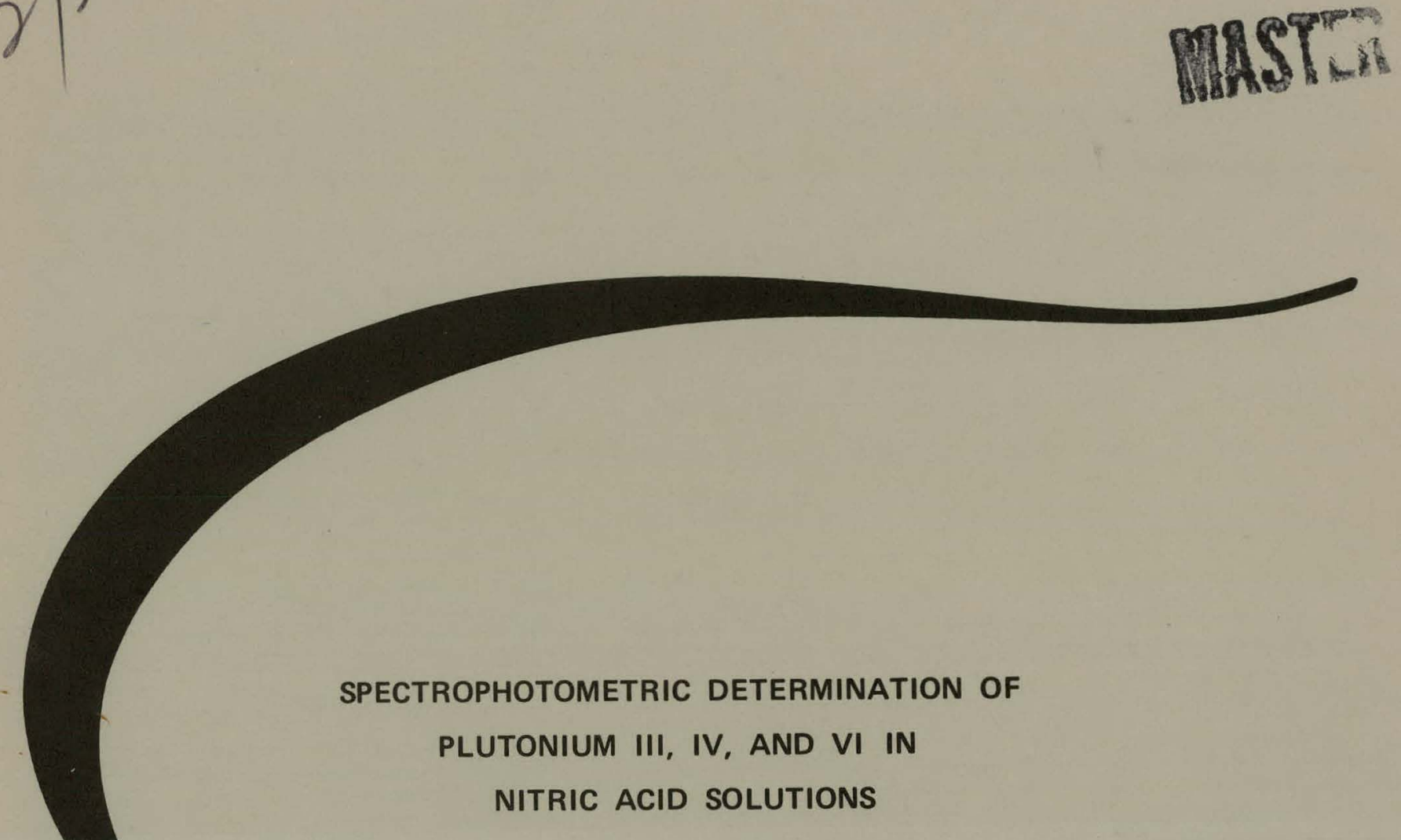

Paul G. Hagan

Frend J. Miner

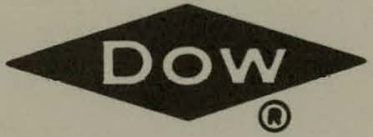

THE DOW CHEMICAL COMPANY

ROCKY FLATS DIVISION

P. O. BOX 888

GOLDEN, COLORADO 80401

U.S. ATOMIC ENERGY COMMISSION

CONTRACI AI(29-1)-1106 


\section{DISCLAIMER}

This report was prepared as an account of work sponsored by an agency of the United States Government. Neither the United States Government nor any agency Thereof, nor any of their employees, makes any warranty, express or implied, or assumes any legal liability or responsibility for the accuracy, completeness, or usefulness of any information, apparatus, product, or process disclosed, or represents that its use would not infringe privately owned rights. Reference herein to any specific commercial product, process, or service by trade name, trademark, manufacturer, or otherwise does not necessarily constitute or imply its endorsement, recommendation, or favoring by the United States Government or any agency thereof. The views and opinions of authors expressed herein do not necessarily state or reflect those of the United States Government or any agency thereof. 


\section{DISCLAIMER}

Portions of this document may be illegible in electronic image products. Images are produced from the best available original document. 


\section{LEGAL NOTICE}

This report was prepared as an account of Government sponsored work. Neither the United States, nor the Atomic Energy Commission, nor any person acting on behalf of the Commission:

A. Makes any warranty or representation, expressed or implied, with respect to the accuracy, completeness, or usefulness of the information contained in this report, or that the use of any information, apparatus, method, or process disclosed in this report may not infringe privately owned rights; or

B. Assumes any liabilities with respect to the use of, or for damages resulting from the use of any information, apparatus, method, or process disclosed in this report.

As used in the above, "person acting on behalf of the Commission" includes any employee or contractor of the Commission, or employee of such contractor, to the extent that such employee or contractor of the Commission, or employee of such contractor prepares, disseminates, or provides access to, any information pursuant to his employment or contract with the Commission, or his employment with such contractor.

Printed in the United States of America Available from

Clearinghouse for Federal Scientific and Technical Information National Bureau of Standards, U. S. Department of Commerce Springfield, Virginia 22151

Price: Printed Copy $\$ 3.00$; Microfiche $\$ 0.65$ 
RFP-1391

UC-4 CHEMISTRY

TID-4500-54th Ed.

\section{SPECTROPHOTOMETRIC DETERMINATION}

OF PLUTONIUM III, IV, AND VI

\section{IN NITRIC ACID SOLUTIONS}

Paul G. Hagan

Frend J. Miner



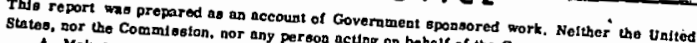
A. Makes any war ranty or nepresenta action on betalf of the Cominl salon

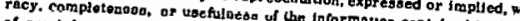
of any informanton, apparatug, method or proceng cantulaed to this report, or that the ung B. Alned righte; or

uso of asy loformath in the

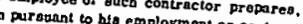
emplayaent with aucb contrnetar.

\footnotetext{
THE DOW CHEMICAL COMPANY

ROCKY FLATS DIVISION

P. O. BOX 888

GOLDEN, COLORADO 80401

Prepared under Contract AT(29-1)-1106

for the

Albuquerque Operations Office

U. S. Atomic Energy Commission
} 


\section{ACKNOWLEDGEMENT}

The authors wish to thank Yvonne M. Ferris of Scientific Systems for her assistance in preparing a computer program for the solution of the determinants, and A. L. Johnston for experimental assistance.

This work was part of the project, "Investigation of the Radiation Chemistry of Plutonium Nitrate Solutions," conduster at Rocky Flats for the Offioe of Safcguards and Materials Management. 
CONTENTS




RFP-1391 


\title{
SPECTROPHOTOMETRIC DETERMINATION OF PLUTONIUM III, IV, AND VI IN NITRIC ACID SOLUTIONS
}

\author{
Paul G. Hagan and Frend J. Miner
}

\begin{abstract}
A method is reported for the quantitative spectrophotometric determination' of plutonium (III), (IV), and (VI) existing separately or in mixed oxidation states in nitric acid. The nitric acid concentration varied from 1 to 4 molar for $\mathrm{Pu}(\mathrm{III})$, and 1 to 10 molar for $\mathrm{Pu}(\mathrm{IV})$ and (VI).

Molar absorptivity values are given for the major absorption peaks with an evaluation of their spectral reproducibility. With these molar absorptivity data and the mathematical approach of Ochsenfeld and Schmieder ${ }^{1}$ a method is presented for a calculation to determine the molar concentration of each oxidation state.
\end{abstract}

\section{SUMMARY}

A method was developed for the quantitative spectrophotometric determination of Pu(III), (IV), and (VI), existing separately or in mixed oxidation states in nitric acid media. The nitric acid concentration varied from 1 to 4 molar for Pu(III), and 1 to $10 \mathrm{molar}$ for Pu(IV) and (VI). The spectra of the separate valent states in varying ooncentrations of nitric acid were prepared. and a study of the anomalies of the major absorption peaks of plutonium was made. Molar absorptivity values were calculated from these absorption peaks and evaluated for their analytical reproducibility.

\section{INTRODUCTION}

Plutonium possesses four oxidation states in aqueous solutions: (III), (IV), (V), and (VI). Because of only slight differences in oxidation - reduction pntentials, these oxidation states can exist simultaneously in solution. In nitric acid, however, Pu(V) is not present in detectable concentrations, and $\mathrm{Pu}(\mathrm{III})$ is only present at acid concentrations of less than five molar.

Spectrophotometric studies of aqueous plutonium systems have been quite extensive. The initial spectrophotometric work, which demonstrated the utility of spectra in plutonium oxidation state analysis, was done by Hindman and Kraus in the early 1940's. ${ }^{2}$ Subsequently, Myers ${ }^{3}$ and Colvin ${ }^{4}$ investigated the absorption spectra of plutonium in nitric acid solutions. They determined molar absorptivity values for Pu(III), (IV), and (VI), and showed how the spectra depended on nitric acid concentration. Colvin developed a series of formulas to calculate the concentration of particular oxidation states from absorbance measurements. Later, Ochsenfeld and Schmieder ${ }^{1}$ improved the data by using a spectrophotometer with better resolution.

The objective of this work was to establish a method to quantitatively determine the concentration of a plutonium valence species in nitric acid solutions containing mixed plutonium valencies. To obtain this objective, a spectrophotometer with good resolving characteristics was used to analyze plutonium solutions of high valence spectral purity. Molar absorptivity data for the major peaks of the various valencies were determined in nitric acid up to $4 \mathrm{M}$ for Pu(III), and to $10 \mathrm{M}$ for Pu(IV) and (VI). These data were then used to obtain equations which permit the rapid calculation of the concentration of an individual valence state in a solution of mixed valencies. Determinates, solved by the computer, were used to obtain the equations.

\section{EXPERIMENTAL}

Four different concentrations of plutonium in nitric acid solutions were prepared for each of the three plutonium valence states.

$\mathrm{Pu}(\mathrm{III})$ from $0.024 \mathrm{M}$ or $5.7 \mathrm{~g} / \mathrm{l}$

to $0.0027 \mathrm{M}$ or $0.6 \mathrm{~g} / \mathrm{l}$

$\mathrm{Pu}$ (IV) from $0.013 \mathrm{M}$ or $3.1 \mathrm{~g} / \mathrm{l}$

to $0.001 \mathrm{M}$ or $0.3 \mathrm{~g} / 1$

$\mathrm{Pu}$ (VI) from $0.0019 \mathrm{M}$ or $0.46 \mathrm{~g} / \mathrm{l}$

to $0.0002 \mathrm{M}$ or $0.005 \mathrm{~g} / \mathrm{l}$

\section{Plutonium Solution}

These plutonium solutions were prepared by culling plutonium metal of high purity to a desired weight 
followed by dissolution in $5 \mathrm{ml}$ of $6 \mathrm{M} \mathrm{HClO}_{4}$ in a volumetric flask. The resulting solutions were primarily Pu(III).

\section{Pu(III) Preparation}

To prevent oxidation, hydroxylamine hydrocholoride was added (the spectra appeared unaffected by the addition of this reductant). Measured quantities of concentrated $\mathrm{HNO}_{3}$ was then added to obtain the desired $\mathrm{HNO}_{3}$ concentrations and the volumetrics were brought to volume with $0.5 \mathrm{M} \mathrm{HClO}_{4}$. Because of the oxidizing properties of $\mathrm{HNO}_{3}$, trivalent plutonium can only be studied in solutions up to $5 \mathrm{M} \mathrm{HNO}_{3}$, and over $4 \mathrm{M}$ the spectral purity of $\mathrm{Pu}(\mathrm{III})$ is questionable.

\section{Pu(IV) Preparation}

To the volumetrics used for the tetravalent solutions, concentrated $\mathrm{HNO}_{3}$ was added to adjust the $\mathrm{HNO}_{3}$ molarity and to oxidize the solutions to the Pu(IV) state. The volumetrics were made to volume with dilute $\mathrm{HClO}_{4}$ and checked for Pu(IV) spectral purity by the absence of $\mathrm{Pu}(\mathrm{III})$ and $\mathrm{Pu}(\mathrm{VI})$.

\section{Pu(VI) Preparation}

A stock solution of hexavalent plutonium was prepared by fuming the excess of perchloric acid used in dissolving the plutonium metal. The solutions were checked spectrophotometrically and found to contain no detectable Pu(III) or Pu(IV). Aliquots were then mixed in volumetric flasks with varying amounts of $10 \mathrm{M} \mathrm{HNO}_{3}$ to yield the desired nitric acid concentrations.

\section{Equipment}

A Cary Model 14 continuous recording spectrophotometer was used for recording the spectra. Solutions were scanned, using $1 \mathrm{~cm}$ cells, from 1300 to $700 \mathrm{~nm}$ in the near infrared region (NIR) and from 700 to $300 \mathrm{~nm}$ in the visible region. A scanning speed of $0.5 \mathrm{~nm} / \mathrm{sec}$ was used for optimum instrumental resolution.
The temperature of the solution in the absorption ccll rose from ambient $\left(\sim 24^{\circ} \mathrm{C}\right)$ to $\sim 32^{\circ} \mathrm{C}$ during the scanning of the NIR reginn. The temperature then dropped lu ambient during the subsequent scanning of the visible region.

\section{RESULT3 AND DISCUSSIÜIN}

\section{Plutonium(III)}

Although trivalent plutonium does not have a tendency to form strong complexes in solution, a slight spectral change is evidenced as the nitrate ion is increased (see Fig. 1). The trivalent plutonium nitrate complex is presumed to be the $\mathrm{Pu}^{3+}$ ion associated with eilher one, two, or three nitrate ions: $\mathrm{Pu}\left(\mathrm{NO}_{3}\right)^{2+}, \mathrm{Pu}\left(\mathrm{NO}_{3}\right)_{2}^{+}$, or $\mathrm{Pu}\left(\mathrm{NO}_{3}\right)_{3}$. Association quulients for these three complexes have been assigned by Shevchenko, et al., 5 from solvent extractions studics. Spectrophotometrically, these complexes cannot presently be differentiated.

Quantitative molar absorptivity values were calculated using the absorbancc values of the principal peaks and selected troughs at constant wavelengths. These values, calculated al various nitric acid concentrations, show the effect of nitratc complex funnation. Pu(III) molar absorptivity values ale listed in Table l. Calculations were made at two major peaks (560 and $600 \mathrm{~nm}$ ) using twn trnughs $(585$ and $610 \mathrm{~nm})$ and the bastliue (450 imi) where any Pu(IV) absurbance would be minimal. Also listed are values at $476 \mathrm{~nm}$, the principal $\mathrm{Pu}(\mathrm{IV})$ peak, which were used to ohock the spectral puity uf Pu(III) with reference to $\mathrm{Pu}(\mathrm{IV})$.

The evaluation shows that the molar absorptivity value obtained using the $560 \mathrm{~nm}$ peak and $640 \mathrm{~nm}$ trough is the most reproducible. The value obtained using the 600 $\mathrm{nm}$ peak with the $640 \mathrm{~nm}$ trough is about as reproducible; however, when either of these two peaks is evaluated with the $585 \mathrm{~nm}$ trough or baseline, the average relative standard deviation increases considerably.

\section{Plutonium(IV)}

Tetravalent plutonium casily combines with nitrate ions forming complexes from $\mathrm{Pu}\left(\mathrm{NO}_{3}\right)^{3+}$ to $\mathrm{Pu}\left(\mathrm{NO}_{3}\right)_{6}^{2-}$. The lower acidities of $\mathrm{HNO}_{3}$ ( 1 to $4 \mathrm{M}$ ) favor the mono-, di-, and trinitrato complexes, whereas the higher acidities promote increasing formation of $\mathrm{Pu}\left(\mathrm{NO}_{3}\right)_{6}^{2-}$. 


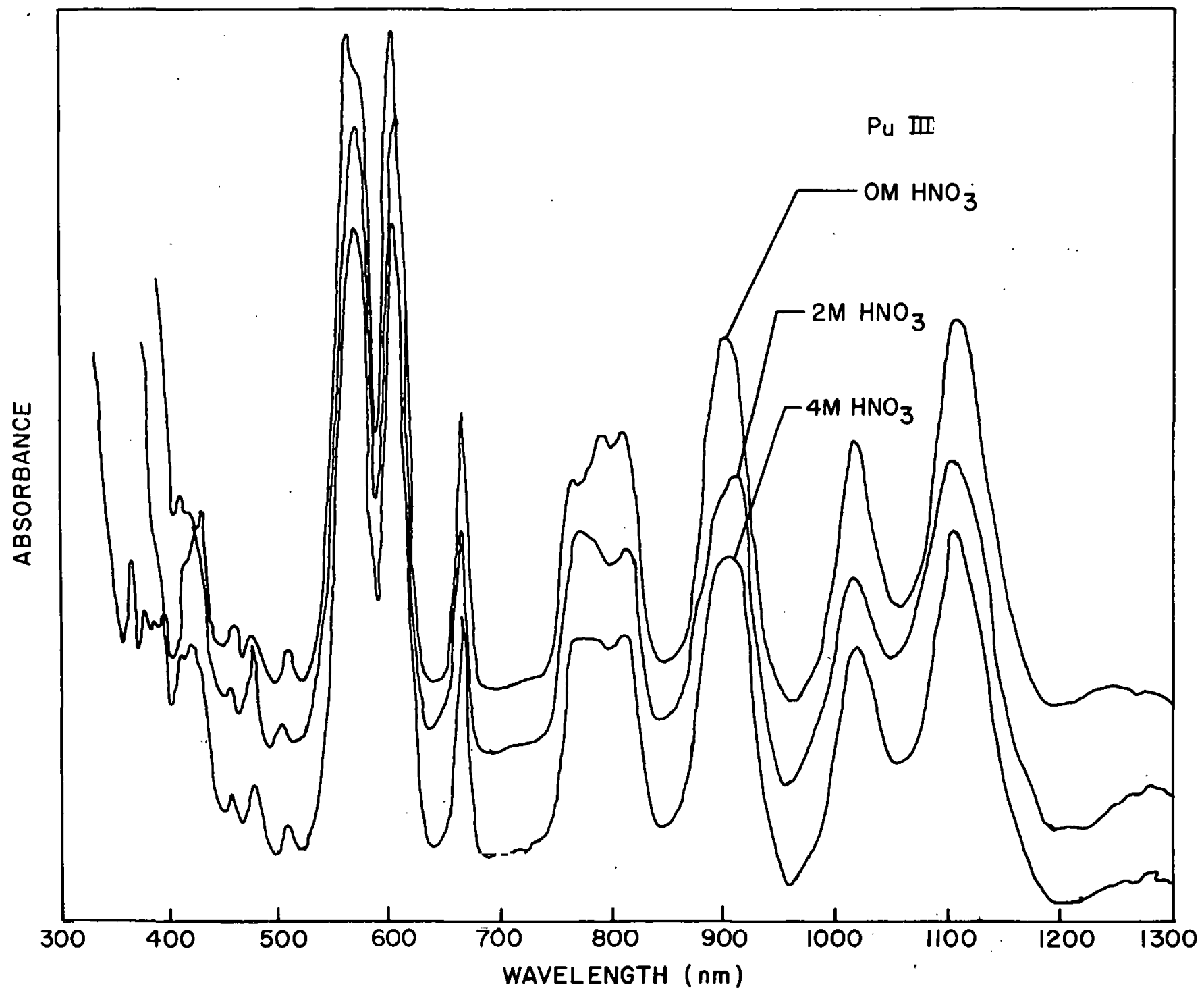

Figure 1. Absorption Spectra of Plutonium III in OM, 2M, and $4 \mathrm{M} \mathrm{HNO}_{3}$.

TABLE I. Relative Molar Absorptivity Values of Plutonium III as a Function of $\mathrm{HNO}_{3}$ Concentration.

\begin{tabular}{|c|c|c|c|c|c|c|c|c|c|c|c|c|c|c|c|c|}
\hline $\mathrm{HNO}_{3}, \mathrm{M}$ & $\begin{array}{l}\text { A } \\
560 \\
n m \\
\bar{\epsilon}\end{array}$ & $\begin{array}{l}\text { A } \\
585 \\
\mathrm{~nm} \\
\pm \mathrm{SD}\end{array}$ & \multicolumn{2}{|c|}{$\begin{array}{ll}\mathrm{A} & \mathrm{A} \\
560 & -640 \\
\mathrm{~nm} & \mathrm{~nm} \\
\bar{E} & \mathrm{ISD}\end{array}$} & \multicolumn{2}{|c|}{$\begin{array}{ll}A & A \\
600 & -585 \\
n m & n m \\
\bar{\epsilon} & \pm S D\end{array}$} & \multicolumn{2}{|c|}{$\begin{array}{lc}A & A \\
600 & -640 \\
n m & n m \\
\bar{\epsilon} & \pm S D\end{array}$} & \multicolumn{2}{|c|}{$\begin{array}{l}\mathrm{A} \\
560-\text { Baseline } \\
\mathrm{nm} \quad \\
\bar{\epsilon} \quad \pm \mathrm{SD}\end{array}$} & \multicolumn{2}{|c|}{$\mid \begin{array}{ll}A & \\
600 & - \text { Baseline } \\
\mathrm{nm} \quad & \\
\vec{\epsilon} \quad \pm \mathrm{SD}\end{array}$} & \multicolumn{2}{|c|}{\begin{tabular}{|lc}
$A$ & $A$ \\
476 & -515 \\
$n m$ & $n m$ \\
$\bar{\epsilon}$ & $\pm S D$
\end{tabular}} & \multicolumn{2}{|c|}{$\begin{array}{l}\mathrm{A} \\
476-\text { Baseline } \\
\mathrm{nm} \quad \\
\bar{\epsilon} \quad \pm \mathrm{SD}\end{array}$} \\
\hline 1 & 20.9 & 0.5 & 36.5 & 0.2 & .20 .9 & 0.9 & 36.5 & 0.6 & 40.5 & 1.7 & 40.4 & 1.4 & 2.6 & 0.3 & 6.7 & 2.1 \\
\hline 2 & 19.2 & 0.8 & 35.6 & 0.7 & 19.9 & 1.2 & 36.3 & 0.9 & 37.3 & 2.1 & 38.0 & 1.6 & 2.4 & 0.2 & 4.3 & 2.4 \\
\hline 3 & 17.7 & 1.0 & 34.8 & 0.6 & 19.9 & 1.1 & 37.5 & 1.2 & 37.4 & 0.9 & 39.0 & 1.8 & 2.8 & 0.8 & 5.5 & 1.3 \\
\hline 4 & 16.4 & * & 30.9 & * & 19.0 & * & 33.5 & 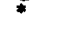 & 35.1 & * & 38.2 & * & 2.6 & * & & \\
\hline
\end{tabular}
RSD (\%)

* Values not Included because of dubious spectral purity. 
Because of the strong tendency for Pu(IV) to form complexes, the tetravalent nitrato spectra experiences considerable peak shifting and transformation (see Fig. 2). The principal peak at $476 \mathrm{~nm}$ shifts to a longer wavelength and decreases in molar absorptivity values as the nitrate concentration increases. Also, significant new peaks are introduced at 443-; 608-, and $743 \mathrm{~nm}$.
Major absorption peaks at 476-, 660-, and $1075 \mathrm{~nm}$ with troughs at 495-, 690-, and $1200 \mathrm{~nm}$, respectively, were used to calsulate the molar abserptivity valuos of Pu(IV). A calculation was also made at the $476 \mathrm{~nm}$ peak using a baseline set to zero at $450 \mathrm{~nm}$. The molar absorptivity at the $476 \mathrm{~nm}$ peak at various acid concentrations was calculated using both a constant wavelength and a

Figure 2. Absorption Spectra of Plutonium IV in $0.5 \mathrm{M}, 6 \mathrm{M}$, and $9 \mathrm{M} \mathrm{HNO}_{3}$.

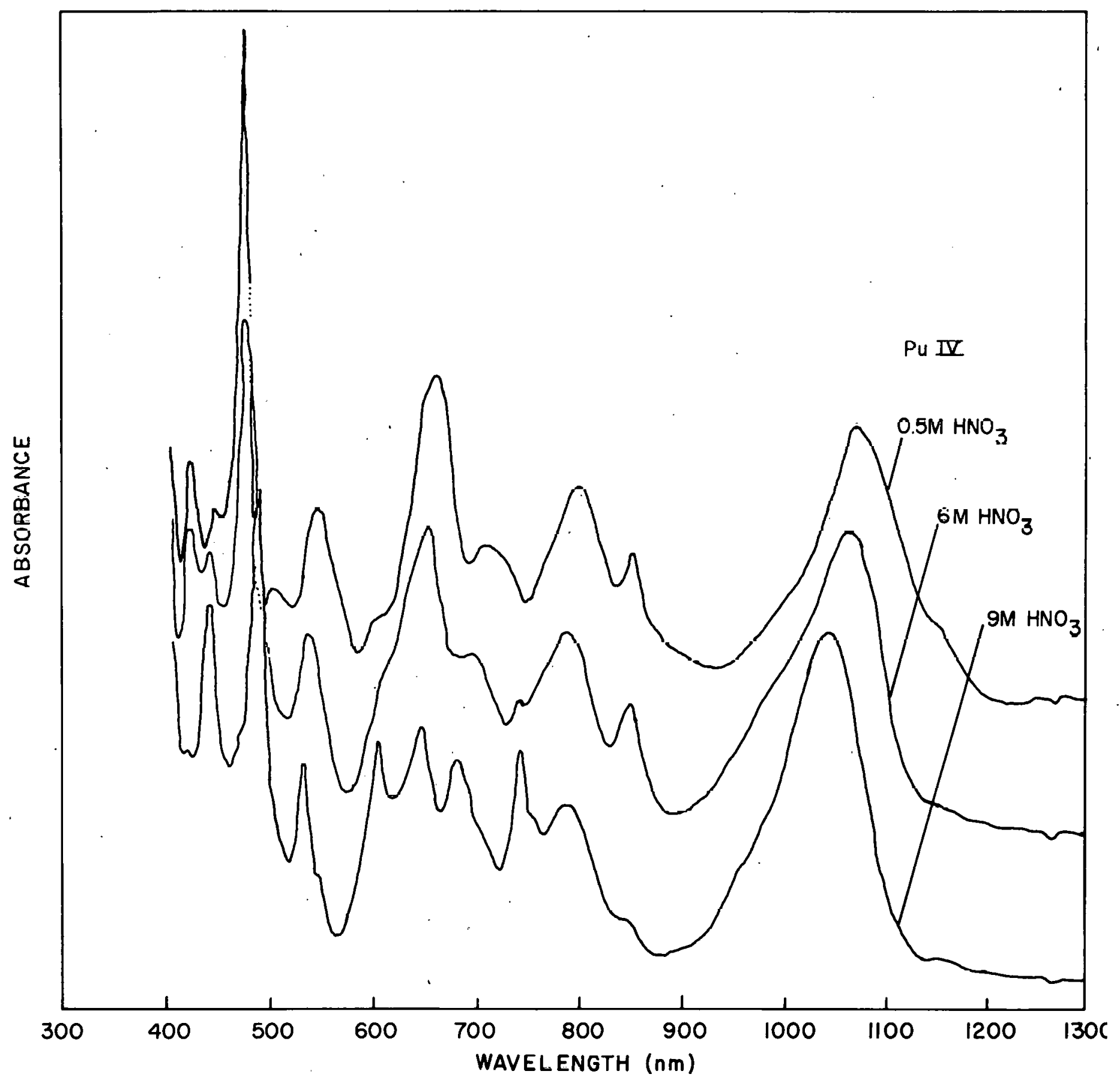


maximum peak height. Both methods have certain drawbacks. Using a constant wavelength, the complexing of the $\mathrm{NO}_{3}^{-}$ions shifts the peak absorbance. Using measurements at maximum peak heights, the observed peak shift, $>15 \mathrm{~nm}$, makes the calculation of mixed valancies slightly inaccurate unless corrections are made for the contribution from absorbance of Pu(III) and $\mathrm{Pu}(\mathrm{VI})$ at the changed wavelengths.

Relative molar absorptivity values for $\mathrm{Pu}(\mathrm{IV})$ are given in Table II. The relative standard deviations show the peak in the NIR region at $1075 \mathrm{~nm}$ to be the most reproducible with changing $\mathrm{HNO}_{3}$ concentrations. The values in the visible region associated with the maximum 476 $\mathrm{nm}$ peak (including shift) and 660 peak have about the same precision.

\section{Plutonium(VI)}

The intense $\mathrm{Pu}(\mathrm{VI})$ peak at $831 \mathrm{~nm}$ in the NIR region (see Figure 3) was used to quantitatively determine the amount of hexavalent plutonium present. In recent years, instrument refinements have increased peak resolution in the NIR region; accordingly, the reported molar absorptivity values of the $831 \mathrm{~nm}$ peak have increased. At the same time, the questionable ability of the $831 \mathrm{~nm}$ peak to follow Beer's law has been resolved as reported by Costanzo and Biggers. ${ }^{6}$
The analytical approach for mixed valency solutions required the instrument to be set in an automatic scan function. The temperature in the absorption cell rose $\sim 8^{\circ} \mathrm{C}$ during the NIR region scan of the solutions. Therefore, consistency of the scanning procedures is important because the absorbancy of the $831 \mathrm{~nm}$ peak has a large negative temperature coefficient, decreasing as the temperature increases.

An increase in nitric acid concentration also causes a decrease in the absorbance of the 831 peak. A plot of absorptivity values with respect to $\mathrm{HNO}_{3}$ concentration is shown in Figure 4. This decrease is attributed to the formation of the various nitrato complexes. Hindman ${ }^{2}$ has reported three nitrate complexes presumed to be $\mathrm{PuO}_{2}\left(\mathrm{NO}_{3}\right)^{+}, \mathrm{PuO}_{2}\left(\mathrm{NO}_{3}\right)_{2}$, and $\mathrm{PuO}_{2}\left(\mathrm{NO}_{3}\right)_{3}^{-}$. Thus, as the nitric acid concentration is increased to $4 \mathrm{M}$, the decrease in absorption of the $831 \mathrm{~nm}$ peak is attributed to the formation of the mono- and dinitrato complexes (this presently can only be substantiated by spectral change). Near $4 \mathrm{M}$ nitric acid, a new peak appears at 815 $\mathrm{nm}$ and is attributed to the trinitrato plutonyl complex. As the nitric acid molarity is increased above $4 \mathrm{M}$, the absorbance of the $815 \mathrm{~nm}$ peak increases while the 831 peak continues to decrease. The absorbance for these two peaks reaches the same value between 9 and 10M nitric acid. In higher nitric acid concentrations, the trinatrato species becomes predominant.

The relative molar absorptivity values for $\mathrm{Pu}(\mathrm{VI})$ are given in Table III. These values are calculated using peaks at $831 \mathrm{~nm}$ and $815 \mathrm{~nm}$ with a trough at $850 \mathrm{~nm}$.

TABLE II. Relative Molar Absorptivity Values of Plutonium IV as a Function of $\mathrm{HNO}_{3}$ Concentration.

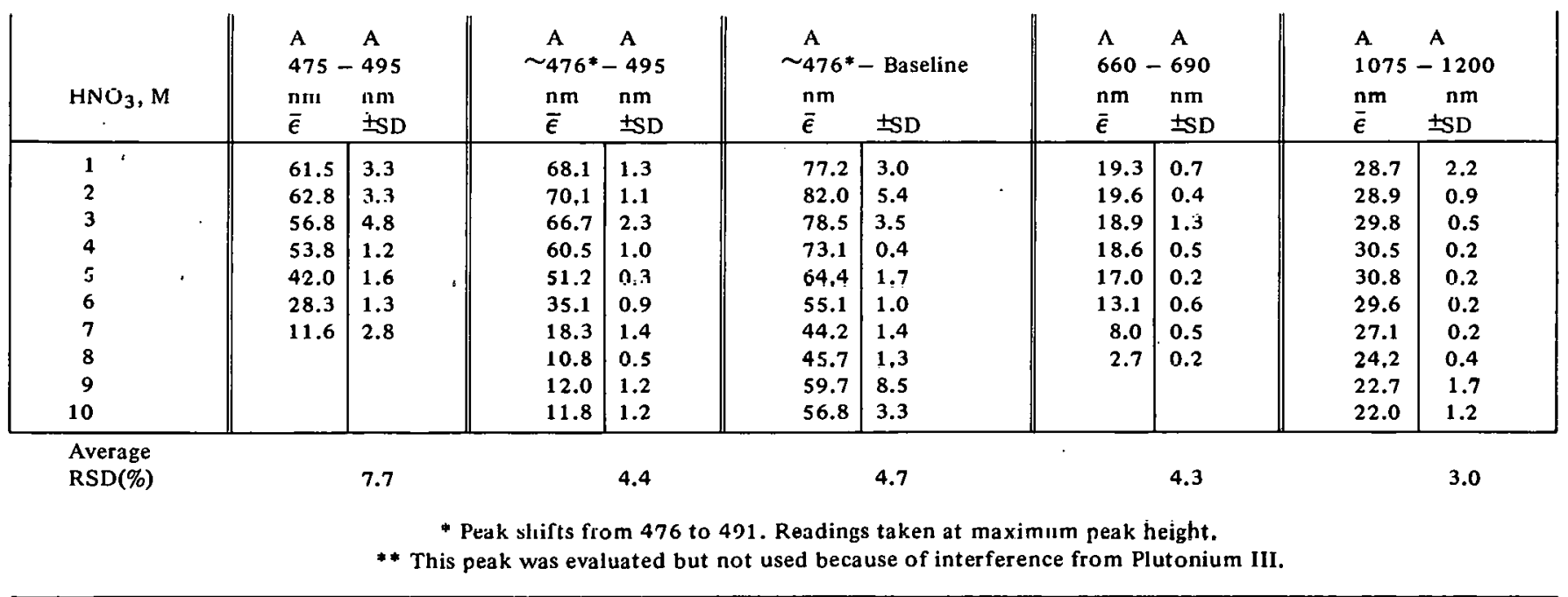


Figure 3. Absorption Spectra of Plutonium VI in $1 \mathrm{M}, 6 \mathrm{M}$, and $9 \mathrm{M} \mathrm{HNO}_{3}$.




TABLE III. Relative Molar Absorptivity Values of Plutonium VI as a Function of $\mathrm{HNO}_{3}$ Concentration.

\begin{tabular}{|c|c|c|c|c|c|c|}
\hline \multirow[t]{2}{*}{$\frac{\mathrm{NNO}_{3}}{\mathrm{M}}$} & \multicolumn{3}{|c|}{ 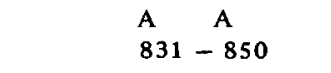 } & \multicolumn{3}{|c|}{$\begin{array}{l}A \quad A \\
815-850\end{array}$} \\
\hline & $\overline{\boldsymbol{\epsilon}}$ & $\pm S D$ & RSD & $\bar{\epsilon}$ & $\pm S D$ & RSD \\
\hline 0 & 502.5 & 11.3 & 2.2 & & & \\
\hline 1 & 469.6 & 11.9 & 2.5 & & & \\
\hline 2 & 447.8 & 5.6 & 1.3 & & & \\
\hline 3 & 426.3 & 9.8 & 2.3 & & & \\
\hline 4 & 372.6 & 3.2 & 0.9 & & & \\
\hline 5 & 318.9 & 6.0 & 1.9 & & & \\
\hline 6 & 246.1 & 5.4 & 2.2 & 28.6 & 1.0 & 3.5 \\
\hline 7 & 174.1 & 1.4 & 0.8 & 42.9 & 0.8 & 1.9 \\
\hline 8 & 117.0 & 0.9 & 0.8 & 55.5 & 1.9 & 3.4 \\
\hline 9 & 73.2 & 4.2 & 5.6 & 65.1 & 0.9 & 1.4 \\
\hline 10 & 48.2 & 0.9 & 1.9 & 69.7 & 0.6 & 0.9 \\
\hline $\begin{array}{l}\text { Aver } \\
\text { RSD }\end{array}$ & & & 2.0 & & & 2.2 \\
\hline
\end{tabular}

Calculations for the Quantitative Determination of the Individual Valencies of Plutonium

The mathematical approach used by Ochsenfeld and Schmieder ${ }^{1}$ is adaptable for calculating the concentration of all three plutonium valencies occurring simul taneously. The method first states that the absorbance of any principal peak is the product of the molar absorptivity value and the molarity of the individual valence species of plutonium. To this principal peak, minor additive values of absorbance are contributed by other valencies of plutonium present. This is given by the following equations:

$$
\begin{aligned}
& \Delta \mathrm{A}_{1}=\epsilon(\mathrm{III})_{11} \cdot \mathrm{M}(\mathrm{III})+\epsilon(\mathrm{IV})_{, 1} \cdot \mathrm{M}(\mathrm{IV})+\epsilon(\mathrm{VI})_{11} \cdot \mathrm{M}(\mathrm{VI}) \\
& \Delta \mathrm{A}_{2}=\epsilon(\mathrm{IV})_{, 2} \circ \mathrm{M}(\mathrm{IV})+\epsilon(\mathrm{III})_{, 2} \cdot \mathrm{M}(\mathrm{III})+\epsilon(\mathrm{VI})_{2} \cdot \mathrm{M}(\mathrm{VI}) \\
& \Delta \mathrm{A}_{3}=\epsilon(\mathrm{VI})_{3} \circ \mathrm{M}(\mathrm{VI})+\epsilon(\mathrm{III})_{3} \cdot \mathrm{M}(\mathrm{III})+\epsilon(\mathrm{IV})_{,_{3}} \cdot \mathrm{M}(\mathrm{IV})
\end{aligned}
$$

Where: $\Delta \mathrm{A}_{1}$ is absorbance at $560 \mathrm{~nm}$ (peak) $-640 \mathrm{~nm}$ (trough)

$\Delta A_{2}$ is absorbance at $476 \mathrm{~nm}$ (peak)

- $495 \mathrm{~nm}$ (trough)

$\Delta \mathrm{A}_{3}$ is absorbance at $831 \mathrm{~nm}$ (peak)

$-850 \mathrm{~nm}$ (trough)

$\epsilon(\text { III })_{1}$ is relative molar absorptivity value from Table IV where the Roman numeral indicates the oxidation state and the Arabic numeral the wavelength at which the absorbance was measured.

$\mathrm{M}(\mathrm{III})$ is molar concentration of $\mathrm{Pu}(\mathrm{III})$, etc. The wavelengths used in the equations above were selected on the basis of having the best precision, as noted in Tables I, II and III, as well as minor interference from other oxidation states.

Figure 4. Molar Absorptivity Decrease of the 831 Peak of Plutonium VI as a Function of $\mathrm{HNO}_{3}$ Concentration.

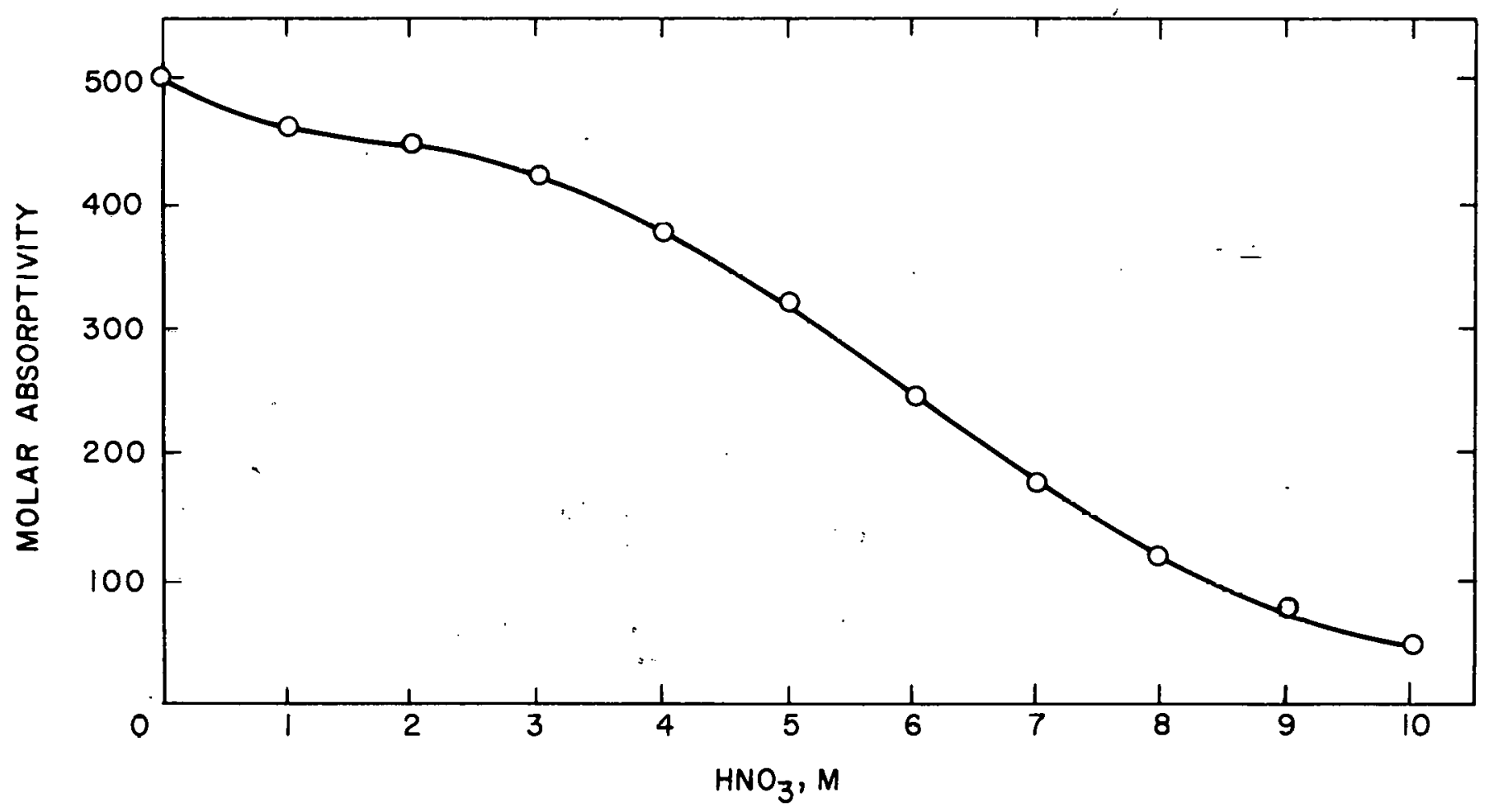




\section{RFP-1391}

Since molar absorptivity values change with nitric acid concentration, a new series of equations are required for each acid concentration of interest.

The preceding series of equations are applicable in solutions of nitric acid to $3 \mathrm{M}$. Exceeding this acid concentration, $\mathrm{Pu}$ (III) is not stable and will oxidize to $\mathrm{Pu}(\mathrm{IV})$. The principal peaks are then attributed to the valencies of $\mathrm{Pu}(\mathrm{IV})$ and (VI) which, for the quantitative calculation, results in two equations with two unknowns:

$$
\begin{aligned}
& \Delta \mathrm{A}_{2}=\epsilon(\mathrm{IV})_{2} \cdot \mathrm{M}(\mathrm{IV})+\epsilon(\mathrm{VI})_{2} \cdot \mathrm{M}(\mathrm{VI}) \\
& \Delta \mathrm{A}_{3}=\epsilon(\mathrm{VI})_{3} \cdot \mathrm{M}(\mathrm{VI})+\epsilon(\mathrm{IV})_{3} \cdot \mathrm{M}(\mathrm{IV})
\end{aligned}
$$

A new peak appears for $\mathrm{Pu}(\mathrm{VI})$ at $6 \mathrm{M} \mathrm{HNO}_{3}$ and is measured at $815 \mathrm{~nm}$ (peak) minus $850 \mathrm{~nm}$ (trough). In the above notation this would be $\Delta \mathrm{A}_{4}, \epsilon(\mathrm{VI})_{4}$ and $\epsilon(I V)_{4}$. which would be substituted for $\Delta A_{3}, \epsilon(V I)_{3}$ and $\epsilon(\mathrm{IV})_{3}$, respectively. The absorbance $\Delta \mathrm{A}_{1}$ is measured at $815 \mathrm{~nm}$ (peak) minus 850 (trough).

All the above mentioned equations can be made more useful for calculating the concentration of the individual valence states by substituting values of molar absorptivity from Table IV and the solving for M (III), (IV), and (VI) by determinants. The resulting equations for each acid concentration are summarized in Table V.

An example of a calculation for a typical plutonium solution is as follows:

A solution of mixed valencies is spectrophotometrically scanned from 1300 to $300 \mathrm{~nm}$. The absorbance from the spectrum is recorded as follows:

$$
\begin{aligned}
& \Delta \mathrm{A}_{1}(560 \text { peak }-640 \text { trough })=-0.130 \\
& \Delta \mathrm{A}_{2}(476 \text { peak }-495 \text { trough })=+0.753 \\
& \wedge \mathrm{A}_{3}\left(831_{2} \text { peak }-850 \text { trough }\right)=+0.217
\end{aligned}
$$

The solution is $1.0 \mathrm{M} \mathrm{HNO}_{3}$; therefore, the equation from Table $\mathrm{V}$ for $1.0 \mathrm{M} \mathrm{HNO}_{3}$ is applied.

$$
\begin{array}{llll}
\mathrm{Pu}(\mathrm{III}), \mathrm{M}=0.0271 & \Delta \mathrm{A}_{1}+0.00599 & \Delta \mathrm{A}_{2}-0.000173 & \Delta \mathrm{A}_{3} \\
\mathrm{Pu}(\mathrm{IV}), \mathrm{M}=0.0145 & \Delta \mathrm{A}_{2}-0.000858 \Delta \mathrm{A}_{1}-0.000138 & \Delta \mathrm{A}_{3} \\
\mathrm{Pu}(\mathrm{VI}), \mathrm{M}=0.00213 \Delta \mathrm{A}_{3}-0.000226 \Delta \mathrm{A}_{1}+0.0000685 & \Delta \mathrm{A}_{2}
\end{array}
$$

Substituting the $\Delta \mathrm{A}$ values and solving for Pu(III), (IV), and (VI):

$$
\begin{aligned}
& (0.0271)(0.130) ।(0.00599)(0.753)=(0.000173)(0.217)= \\
& 0.00095 \mathrm{M} \text { or } 0.23 \mathrm{~g} / 1 \mathrm{Pu}(\mathrm{III})
\end{aligned}
$$
$(0.0145)(0.753)-(0.000858)(-0.130)-(0.000138)(0.217)=$ $0.011 \mathrm{M}$ or $2.63 \mathrm{~g} / 1 \mathrm{Pu}(\mathrm{IV})$
$(0.00213)(0.217)-(0.000226)(-0.130)+(0.0000685)(0.753)=$ $0.00054 \mathrm{M}$ or $0.13 \mathrm{~g} / 1 \mathrm{Pu}(\mathrm{VI})$

\begin{tabular}{|c|c|c|}
\hline $\mathrm{HNO}_{3}, \mathrm{M}$ & $\begin{array}{l}\text { PuIII } \\
\vec{e}_{\text {IIII }}\end{array}$ & $\begin{array}{l}\text { PuIV } \\
\bar{\epsilon} I^{\prime} V_{1}\end{array}$ \\
\hline 1 & 36.5 & -15.1 \\
\hline 2 & 35.6 & -17.6 \\
\hline 3 & 34.8 & -18.4 \\
\hline 4 & 30.9 & -19.4 \\
\hline
\end{tabular}

Total plutonium present $=2.99 \mathrm{~g} / 1$

\begin{abstract}
Absolute molar absorptivity values are dependent on the resolution of the spectrophotometer used to measure the absorbance. Fur maximum accuracy, molar absorptivity values should be determined using the spectrophotometer that will be used for subsequent analyses and the values in Table $\mathrm{V}$ recalctilated.
\end{abstract}

TABLE IV. Relative Molar Absorptivity Values for Plutonium III, IV, and VI ạ a Fu Function of $\mathrm{HNO}_{3}$ Consentratinn.

\begin{tabular}{lc} 
A & A \\
560 & -640 \\
$n m$ & $n m$ \\
\hline
\end{tabular}

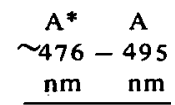

$\begin{array}{lll}\text { PuIV } & \text { PuIII } & \text { PuV } \\ \text { EIV }_{2} & \text { E'III } & \text { EVI } \\ 68.1 & 2.2 & 4.6 \\ 70.1 & 2.1 & 4.9 \\ 66.7 & 2.5 & 5.3 \\ 60.5 & & 5.4 \\ 51.2 & & 6.3 \\ 35.1 & & 6.9 \\ 18.3 & & 7.4 \\ 10.8 & & 7.9 \\ 12.0 & & 8.8 \\ 11.8 & & 8.4\end{array}$

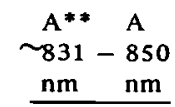

PuVI PuIII PuIV

$\bar{\epsilon} \mathrm{VI}_{3} \quad \bar{\epsilon} \mathrm{III}_{3} \quad \bar{\epsilon} \mathrm{IV}_{3}$

$\begin{array}{lll}469.6 & 3.8 & -3.8\end{array}$

$\begin{array}{lll}117.8 & 2.8 & -5.3\end{array}$

$\begin{array}{lll}426.3 & 3.1 & -6.6\end{array}$

$372.6-6.0$

$318.9-5.2$

$246.1-4.0$

$174.4-1.7$

$117.0 \quad-0.4$

$73.2 \quad 2.1$

$48.2 \quad 3.0$
$\begin{array}{rr}A & A \\ 815 & -850 \\ n m & n m\end{array}$

PuVI PuIV

$\bar{\epsilon} I_{4} \quad \bar{\epsilon} V_{4}$

$28.6 \quad 2.3$

42.94 .0

$55.5 \quad 5.5$

$65.1 \quad 7.1$

$69.7 \quad 7.7$

${ }^{*}$ Peak shifts from 476 lo 491 . Readings taken at maximum peak height.

** Peak shifts from 831 to 830 . Readings taken at maximum peak height.

Note: All trough subtractions made at constant wavelengths. 
TABLE V. Equations for Calculating Plutonium Concentrations.

\begin{tabular}{|c|c|c|c|c|}
\hline $\mathrm{HNO}_{3}, \mathrm{M}$ & & & & \\
\hline 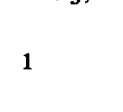 & $\begin{array}{l}\mathrm{Pu}(\mathrm{III}), \mathrm{M}= \\
\mathrm{Pu}(\mathrm{IV}), \mathrm{M}= \\
\mathrm{Pu}(\mathrm{VI}), \mathrm{M}=\end{array}$ & $\begin{array}{ll}0.0271 & \Delta \mathrm{A}_{1} \\
0.0145 & \triangle \mathrm{A}_{2} \\
0.00213 & \triangle \mathrm{A}_{3}\end{array}$ & $\begin{array}{l}+0.00599 \Delta \mathrm{A}_{2} \\
-0.000858 \Delta \mathrm{A}_{1} \\
-0.000226 \Delta \mathrm{A}_{1}\end{array}$ & $\begin{array}{l}-0.000173 \\
-0.000138 \\
+0.0000685\end{array}$ \\
\hline 2 & $\begin{array}{l}\mathrm{Pu}(\mathrm{III}), \mathrm{M}= \\
\mathrm{Pu}(\mathrm{IV}), \mathrm{M}= \\
\mathrm{Pu}(\mathrm{VI}), \mathrm{M}=\end{array}$ & $\begin{array}{ll}0.0277 & \triangle \mathrm{A}_{1} \\
0.0140 & \triangle \mathrm{A}_{2} \\
0.00223 & \triangle \mathrm{A}_{3}\end{array}$ & $\begin{array}{l}+0.00694 \Delta \mathrm{A}_{2} \\
-0.000816 \Delta \mathrm{A}_{1} \\
-0.000183 \Delta \mathrm{A}_{1}\end{array}$ & $\begin{array}{l}-0.000199 \\
-0.000150 \\
+0.000123\end{array}$ \\
\hline 3 & $\begin{array}{l}\mathrm{Pu}(\mathrm{III}), \mathrm{M}= \\
\mathrm{Pu}(\mathrm{IV}), \mathrm{M}= \\
\mathrm{Pu}(\mathrm{VI}), \mathrm{M}=\end{array}$ & $\begin{array}{ll}0.0282 & \Delta \mathrm{A}_{1} \\
0.0147 & \triangle \mathrm{A}_{2} \\
0.00234 & \triangle \mathrm{A}_{3}\end{array}$ & $\begin{array}{ll}+0.00776 & \Delta \mathrm{A}_{2} \\
-0.00104 & \Delta \mathrm{A}_{1} \\
-0.000221 & \Delta \mathrm{A}_{1}\end{array}$ & $\begin{array}{l}-0.000228 \\
-0.000177 \\
+0.000170\end{array}$ \\
\hline 4 & $\begin{array}{l}\mathrm{Pu}(\mathrm{IV}), \mathrm{M}= \\
\mathrm{Pu}(\mathrm{VI}), \mathrm{M}=\end{array}$ & $\begin{array}{l}0.0165 \quad \Delta A_{2} \\
0.00268 \Delta A_{3}\end{array}$ & $\begin{array}{l}-0.000239 \Delta \mathrm{A}_{3} \\
+0.000266 \Delta \mathrm{A}_{2}\end{array}$ & \\
\hline 5 & $\begin{array}{l}\mathrm{Pu}(\mathrm{IV}), \mathrm{M}= \\
\mathrm{Pu}(\mathrm{VI}), \mathrm{M}=\end{array}$ & $\begin{array}{l}0.0195 \quad \Delta \mathrm{A}_{2} \\
0.00313 \Delta \mathrm{A}_{3}\end{array}$ & $\begin{array}{r}-0.000385 \Delta A_{3} \\
+0.000318 \Delta A_{2}\end{array}$ & \\
\hline 6 & $\begin{array}{l}\mathrm{Pu}(\mathrm{IV}), \mathrm{M}= \\
\mathrm{Pu}(\mathrm{VI}), \mathrm{M}=\end{array}$ & $\begin{array}{ll}0.0284 & \Delta \mathrm{A}_{2} \\
0.00405 & \Delta \mathrm{A}_{3}\end{array}$ & $\begin{array}{l}-0.000796 \Delta \mathrm{A}_{3} \\
+0.000462 \Delta \mathrm{A}_{2}\end{array}$ & \\
\hline $6^{*}$ & $\begin{array}{l}\mathrm{Pu}(\mathrm{IV}), \mathrm{M}= \\
\mathrm{Pu}(\mathrm{VI}), \mathrm{M}=\end{array}$ & $\begin{array}{ll}0.0289 & \Delta A_{2} \\
0.0355 & \Delta A_{4}\end{array}$ & $\begin{array}{ll}-0.00698 & \Delta A_{4} \\
-0.00233 & \Delta A_{2}\end{array}$ & \\
\hline 7 & $\begin{array}{l}\mathrm{Pu}(\mathrm{IV}), \mathrm{M}= \\
\mathrm{Pu}(\mathrm{VI}), \mathrm{M}=\end{array}$ & $\begin{array}{l}0.0544 \quad \Delta_{A_{2}} \\
0.00571 \Delta \mathrm{A}_{3}\end{array}$ & $\begin{array}{l}-0.00231 \triangle \mathrm{A}_{3} \\
+0.000531 \Delta \mathrm{A}_{2}\end{array}$ & \\
\hline $7^{*}$ & $\begin{array}{l}\mathrm{Pu}(\mathrm{IV}), \mathrm{M}= \\
\mathrm{Pu}(\mathrm{VI}), \mathrm{M}=\end{array}$ & $\begin{array}{ll}0.0568 & \Delta \mathrm{A}_{2} \\
0.0242 & \Delta \mathrm{A}_{4}\end{array}$ & $\begin{array}{ll}-0.00980 & \Delta A_{4} \\
-0.00529 & \Delta \Lambda_{2}\end{array}$ & . \\
\hline 8 & $\begin{array}{l}\mathrm{Pu}(\mathrm{IV}), \mathrm{M}= \\
\mathrm{Pu}(\mathrm{VI}), \mathrm{M}=\end{array}$ & $\begin{array}{ll}0.0924 & \Delta \mathrm{A}_{2} \\
0.00853 & \Delta \mathrm{A}_{3}\end{array}$ & $\begin{array}{l}-0.00624 \Delta \mathrm{A}_{3} \\
+0.000316 \Delta \mathrm{A}_{2}\end{array}$ & \\
\hline $8^{*}$ & $\begin{array}{l}\mathrm{Pu}(\mathrm{IV}), \mathrm{M}= \\
\mathrm{Pu}(\mathrm{VI}), \mathrm{M}=\end{array}$ & $\begin{array}{ll}0.0998 & \Delta \mathrm{A}_{2} \\
0.0194 & \Delta \mathrm{A}_{4}\end{array}$ & $\begin{array}{ll}-0.0142 & \Delta \mathrm{A}_{4} \\
-0.00989 & \Delta \mathrm{A}_{2}\end{array}$ & \\
\hline 9 & $\begin{array}{l}\mathrm{Pu}(\mathrm{IV}), \mathrm{M}= \\
\mathrm{Pu}(\mathrm{VI}), \mathrm{M}=\end{array}$ & $\begin{array}{ll}0.0851 & \Delta \mathrm{A}_{2} \\
0.0140 & \Delta \mathrm{A}_{3}\end{array}$ & $\begin{array}{ll}-0.0102 & \Delta A_{3} \\
-0.00244 & \Delta A_{2}\end{array}$ & \\
\hline $9^{*}$ & $\begin{array}{l}\text { Pu(IV),M = } \\
\text { Pu(VI),M = }\end{array}$ & $\begin{array}{ll}0.0906 & \triangle \mathrm{A}_{2} \\
0.0167 & \triangle \mathrm{A}_{4}\end{array}$ & $\begin{array}{ll}-0.0122 & \Delta A_{4} \\
-0.00988 & \Delta A_{2}\end{array}$ & \\
\hline 10 & $\begin{array}{l}\mathrm{Pu}(\mathrm{IV}), \mathrm{M}= \\
\mathrm{Pu}(\mathrm{VI}), \mathrm{M}=\end{array}$ & $\begin{array}{ll}0.0887 & \Delta \mathrm{A}_{2} \\
0.0217 & \wedge \mathrm{A}_{3}\end{array}$ & $\begin{array}{ll}-0.0155 & \triangle_{A_{3}} \\
-0.00552 & \wedge \mathrm{A}_{2}\end{array}$ & \\
\hline $10^{*}$ & $\begin{array}{l}\mathrm{Pu}(\mathrm{IV}), \mathrm{M}= \\
\mathrm{Pu}(\mathrm{VI}), \mathrm{M}=\end{array}$ & $\begin{array}{ll}0.0920 & \Delta A_{2} \\
0.0156 & \Delta A_{1}\end{array}$ & $\begin{array}{ll}-0.0111 & \Delta \mathrm{A}_{4} \\
-0.0102 & \Delta \mathrm{A}_{2}\end{array}$ & \\
\hline
\end{tabular}

\section{Reproducibility}

The precision of the method is measured by the relative standard deviation (RSD) of the relative molar absorptivity values (Tables I, II, and III). The precision varies with the valencies with an RSD of $1.36 \%$ for $\mathrm{Pu}(\mathrm{III})$, $2.0 \%$ for $\mathrm{Pu}(\mathrm{VI})$ and $4.4 \%$ for $\mathrm{Pu}(\mathrm{IV})$.

The accuracy of the method could vary with the ratio of valencies and acid concentrations. A nominal measure of the accuracy was obtained by dissolving weighed metal samples and oxidizing aliquots of these solutions. Then known volumes of these solutions were combined and the resulting mixture analyzed for the concentration of the various valencies. The experimental concentrations of the individual valencies were added and the sum compared with the total plutonium known to be in the solution.

The data from these analyses is given in Table VI.

Table VI. Analytical Accuracy.

\begin{tabular}{|c|c|c|c|c|c|c|c|}
\hline \multirow[b]{2}{*}{$\begin{array}{c}\text { Sample } \\
\text { No. }\end{array}$} & \multirow[b]{2}{*}{$\begin{array}{c}\mathrm{HNO}_{3}, \\
\mathrm{M} \\
\end{array}$} & \multicolumn{4}{|c|}{ Experimental Plutonium Concentration (g/1) } & \multicolumn{2}{|c|}{ Total } \\
\hline & & Pu (III) & Pu (IV) & Pu (VI) & Pu, Total & $\begin{array}{c}\text { Pu Conc. } \\
g / 1\end{array}$ & $* \%$ Diff. \\
\hline 1 & 1 & 0.23 & 2.63 & 0.13 & 2.99 & 2.86 & 4.55 \\
\hline 2 & 1 & 0.70 & 1.69 & $<0.003$ & 2.39 & 2.50 & -4.40 \\
\hline 3 & 2 & 0.04 & 2.51 & $<0.003$ & 2.55 & 2.50 & 2.00 \\
\hline 4 & 5 & 0 & 1.01 & 0.17 & 1.18 & 1.24 & -4.39 \\
\hline 5 & 5 & 0 & 20.7 & $<.03$ & 20.7 & 21.1 & -1.90 \\
\hline 6 & 8 & 0 & 2,14 & 0.44 & 2.58 & 2.47 & 4.45 \\
\hline
\end{tabular}




\section{BIBLIOGRAPHY}

1. Ochsenfeld, W. and Schmieder, H., "Spectrophotometric Determination of Plutonium Valencies in Nitric Acid Solutions." United States-Euratom Fast Reactor Exchange Program EURFNR-386, 1967 [Origianal Report Number KFK 610, 1967].

2. Hindman, J. C., et al. in "The Transuranium Elements," Seaborg, G. T., Katz, J. J., and Manning, W. M., Eds., National Nuclear Energy Series IV, 14-B, McGraw-Hill Book Co, New York, 1946, pp 384, 388 , and 608 .

3. Myers, M. N., "Absorption Spectra of Plutonium and Impurity Ions in Nitric Acid Solution," U. S. Atomic Energy Commission Report HW44744, 1956.

4. Colvin, C. A., "Quantitative Determination of Plutonium Oxidation States in Variable Nitric Acid
Solutions for Control Laboratorics, Spcctrophoto metric," U. S. Atomic Energy Commission Report RL-SA-33, 1965.

5. Shevchenko, V. B., Timoshev, V. G., and Volkova, A. A., "Stability Constants of Nitrate Complexes of Trivalent Plutonium in Aqueous and Tributyl Phosphate Solutions." Soviet J. At. Energy, 6, 293 (1959).

6. Constanzo, D. A., and Biggers, R. E., "A Study of the Polymerization, Depolymerization, and Precipitation of Tetravelent Plutonium as Functions of Temperature and Acidily by Spectrophotometric Methods." U. S. Atomic Energy Commission Report ORNL-TM-585, 1963.

7. Hindman, J. C. in "The Actinide Elements," Seaborg, G. T., and Katz, J. J., Eds., National Nuclear Energy Series IV, 14:A, Mrr.raw-Hill Book. Co., Now York, 1954. p 301. 